\title{
Medical Curricula on Intimate Partner Violence in Mozambique
}

\section{Currículo Médico sobre Violência Perpetrada pelo Parceiro Íntimo em Moçambique}

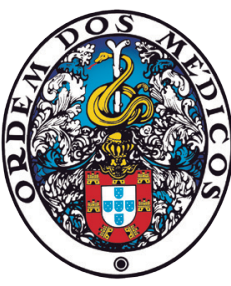

\author{
Beatriz MANUEL $\bigotimes^{1,2}$, Kristien ROELENS ${ }^{3}$, Armindo TIAGO ${ }^{4}$, Ines KEYGNAERT ${ }^{2}$, Martin VALCKE ${ }^{5}$ \\ Acta Med Port 2020 Jan;33(1):22-30 - https://doi.org/10.20344/amp.12049
}

\begin{abstract}
Introduction: The aim of the study described in this paper is to screen medical curricula in relation to the attention paid to intimate partner violence, by applying a framework derived from the international literature.

Material and Methods: We screened curricula of five Mozambican medical schools based on a state-of-the-art intimate partner violence curriculum framework. The latter framework was based on a review of the literature.

Results: Few medical schools of Mozambique could be identified addressing intimate partner violence in their curriculum. When tackled, intimate partner violence content is mostly dealt within the context of Obstetrics and Gynaecology, Community Health and Forensic Medicine rotations. Intimate partner violence contents are integrated as stand-alone modules in some specific subjects. In none of the schools, specific teachers teaching intimate partner violence could be identified. No time allocation was specified to address the topic; no teaching and learning strategies could be identified invoking awareness or supporting basic knowledge acquisition; additionally, hardly any information about related assessment methods was found. Only in one medical school was the subject part of the formal curriculum.
\end{abstract}

Discussion: Intimate partner violence content is hardly and inconsistently addressed. The limited intimate partner violence content tracked in the Mozambican medical schools' curricula, mainly addresses violence in general, for instance as identified in Orthopaedics or Surgery contexts and sexual violence in Obstetrics and Gynaecology. The inclusion of elements of intimate partner violence in the curriculum remains restricted, questioning the impact of medical education of future practitioners' competencies.

Conclusion: Critical changes are needed in medical curricula to match the current epidemiology of intimate partner violence in Mozambique.

Keywords: Competencies; Curriculum; Intimate Partner Violence; Medical Students; Mozambique

\section{RESUMO}

Introdução: O objetivo do estudo descrito neste artigo foi o de examinar os currículos de medicina quanto à atenção dada aos conteúdos sobre a Violência Perpretada pelo Parceiro Íntimo em Moçambique, aplicando uma ferramenta de comparação derivada da literatura internacional.

Material e Métodos: Examinámos os currículos de cinco escolas médicas moçambicanas com base numa estrutura curricular da Violência Perpretada pelo Parceiro Íntimo de última geração. A ferramenta de comparação foi baseada numa revisão da literatura anterior. Resultados: Poucas escolas de medicina de Moçambique podem ser identificadas abordando a Violência Perpretada pelo Parceiro Íntimo no seu currículo. Se abordada, a Violência Perpretada pelo Parceiro Íntimo é mais tratada no contexto de Ginecologia e Obstetricia, Saúde Comunitária e Medicina legal. Os conteúdos da Violência Perpretada pelo Parceiro Íntimo são integrados como módulos autónomos em algumas disciplinas específicas. Nenhum dos curriculos identificou professores específicos que leccionam Violência Perpretada pelo Parceiro Intimo. Não foi especificada a alocação de tempo para abordar o tópico; estratégias de ensino e aprendizagem, sensibilização e aquisição de conhecimentos básicos; e dificilmente informação sobre métodos de avaliação específicos. Apenas numa escola de medicina, o assunto fazia parte do currículo formal.

Discussão: O conteúdo da Violência Perpretada pelo Parceiro Íntimo é dificil e inconsistentemente tratado. O conteúdo limitado da Violência Perpretada pelo Parceiro Íntimo rastreado nos currículos das escolas médicas moçambicanas aborda principalmente a violência em geral, por exemplo, conforme identificado em contextos de ortopedia ou cirurgia e violência sexual em Ginecologia e Obstetrícia. A implementação no currículo permanece restrita, questionando o impacto da educação médica nas competências dos futuros profissionais.

Conclusão: São necessárias mudanças críticas nos currículos médicos para corresponder à actual epidemiologia da Violência Perpretada pelo Parceiro Íntimo em Moçambique.

Palavras-chave: Competências; Currículo; Estudantes de Medicina; Moçambique; Violência Perpretada pelo Parceiro Íntimo

\section{INTRODUCTION}

Intimate Partner Violence (IPV) is defined as "any behaviour within an intimate relationship that leads to physical, psychological or sexual harm to those in that relationship." It is a serious, worldwide public health concern, affecting both women and men.

In many cases, medical doctors are the first point of contact of victims of IPV, which could be an opportunity to offer appropriate care. ${ }^{2}$ However, research points at reluctance

1. Department of Community Health. Faculty of Medicine. University Eduardo Mondlane. Maputo. Mozambique.

2. Department of Public Health and Primary Care. Faculty of Medicine and Health Sciences. Ghent. Belgium.

3. Department of Obstetrics and Gynaecology. Faculty of Medicine and Health Sciences. Ghent University. Ghent University Hospital. Ghent. Belgium.

4. Department of Physiology. Faculty of Medicine. University Eduardo Mondlane. Maputo. Mozambique.

5. Department of Educational Studies. Ghent University. Ghent. Belgium.

$\bowtie$ Autor correspondente: Beatriz Manuel. chonguile@gmail.com

Recebido: 13 de março de 2019 - Aceite: 24 de setembro de 2019 | Copyright @ Ordem dos Médicos 2020 
in medical doctors to ask about abuse, or to respond appropriately. ${ }^{2,3}$ Lack of IPV-related training leads to a lack of IPV screening, lack of confidence in dealing with IPV victims and therefore weak referral or intervention. ${ }^{4-6}$ The available literature shows that IPV elements in medical curricula are not standardized and that medical doctors hardly receive effective or any training at all resulting in a lack of appropriate competencies to deal with IPV. ${ }^{7,8}$ In contrast, other research findings show that IPV curricula can help in improving medical doctors' self-efficacy to identify and manage victims of IPV leading to an increase in referral rates. ${ }^{9-11}$

Although IPV is increasingly recognized as a public health issue that can lead to fatal outcomes, few studies address how medical doctors in Africa are prepared to deal with victims. This study seeks to fill this gap by assessing how IPV elements are addressed in medical curricula in Mozambique.

\section{Addressing IPV in Mozambique}

Osorio et $a /^{12}$ conducted an analysis of the application of the law against domestic violence from 2009 to 2015 in Mozambique and reported that the percentage of women who suffered physical violence (in the 12 months prior to the survey) was $33 \%$ and that of men $25 \%$, with the $15-19$ age group having the lowest prevalence, while for men this age group is where most cases of violence are reported. Osorio and colleagues ${ }^{12}$ added that for both men and women (but more for women with about $39 \%$ versus just over $26 \%$ of assaulted men) more cases of physical violence are reported in urban areas. They also added that these findings need to be analysed cautiously because of the relationship between awareness of the law and behavior change since the victims are living in urban areas.

The provinces of Maputo, Maputo city, Sofala and Gaza have the highest number of cases of violence against women, while for men it is the province of Niassa (with almost $50 \%$ ), Cabo Delgado and Maputo city. ${ }^{12}$ The same authors reported that urban areas, particularly for women in Maputo city, are recognized as being the most violent, which may be related to the level of crime associated with the low capacity of law enforcement, especially at night, where many women circulate (e.g. women returning from school). On the other hand, violence occurs in divorced, separated and widowed women and men.

Physical violence was higher in women in the $20-24$, 25 - 29 and 40 - 49 age groups, and was lower in the 15 - 19 and 15 - 17 age groups (17\% and $15 \%$, respectively), unlike in men, where violence is particularly rife in the latter age groups. ${ }^{12}$ Physical or sexual violence had the highest proportion for both sexes (37\% for women and $29 \%$ for men) and was more frequent in the age group of 20 - 24 years in women, being more prevalent in men aged $15-17$ years $(31 \%) .^{12}$

Regarding the perpetrators of physical violence, Osorio and colleagues ${ }^{12}$ found that $62 \%$ of women stated that the perpetrator was the current spouse or partner, and among non-single women, the percentage rises to $70 \%$. With regards to men, in $27 \%$ of cases the biggest perpetrators of violence are also the wives or partners, and in non-single victims, the percentage was around $13 \% .{ }^{12}$ When talking about the type of spouse abuse in the last 12 months, Osorio and colleagues found that about $33 \%$ of women and $16 \%$ of men have suffered physical and/or sexual violence in the last 12 months. Moreover, about $18 \%$ of women reported slapping as the main form of physical violence, while for men it was only $5 \%$.

In 2015, the $67^{\text {th }}$ World Health Assembly adopted a resolution to enhance the capacities of all public and private professionals in the health and non-health sectors ${ }^{13}$ to improve care for IPV and sexual violence victims. This resolution called for (re)designing and developing curricula to strengthen related knowledge, skills and attitudes. This leads to the question of whether Mozambican medical schools' curricula are up to date as far as IPV is concerned.

The study aims to address the following gaps in research and evidence: "more and better programme evaluation is needed to assess promising practices, and to identify and develop new approaches that can be tested through randomised controlled trials or other rigorous approaches." and "(...) countries will need to know what the most effective clinical care interventions are, and what works for strengthening capacity of health-care providers and to scale up services." ${ }^{14}$

\section{MATERIAL AND METHODS}

In order to identify information about medical curricula in Mozambican medical schools, we did an extensive search to track peer-reviewed articles about IPV in Mozambican medical curricula. Due to a lack of published information, an alternative approach was developed, based on a systematic analysis of concrete medical curricula with follow-up interviews in Mozambican medical schools. The latter requires a curriculum analysis framework to direct the interviews. We built on the study by Taba ${ }^{15}$ to identify key questions to be asked: What are the aims to be achieved? What learning experiences will be invoked in what way? How are teaching and learning organized? The latter questions raise issues about the didactical strategies being adopted, the assessment approaches to check mastery of the curriculum's aims, the structure of the curriculum (courses and build-up), and about the teachers taking up teaching responsibilities (see Appendix 1: https://www.actamedicaportuguesa.com/ revista/index.php/amp/article/view/12049/Appendix_01. pdf). With these questions in mind, further analysis of the literature helped to develop the nature of the interview questions. ${ }^{16}$

Mozambique has seven medical schools; four are public and three are private schools. The schools are - from a regional perspective - equally distributed throughout the country. Five medical schools in Mozambique were contacted to gather information about their medical curricula. The selection was based on their geographical location, especially due to the stretched nature of Mozambique as a country. Next, we selected schools on the basis of the 
largest volume of students: South $(n=2)$ - one private and one public, Centre $(n=2)$ - one private and one public, and the last populated North part of Mozambique $(n=1)$ - a public medical school. To respect anonymity, medical schools are designed as A, B, C, D and E in the result tables.

The following research questions guided this study:

(1) Building on the literature framework, which of the IPV-competence key areas are focused upon in current medical curricula in Mozambique (knowledge, skills, and attitudes)?
(2) What are the strengths and weaknesses of medical curricula in Mozambique, considering the curriculum-related questions (teaching/learning strategies, evaluation approaches, phase in the curriculum, nature of module/discipline, teacher)?

Initial information about the curricula of each university was collected via email and through the Internet. Research assistants obtained electronic versions of courses and modules regarding IPV contents. Curricula were screened on the basis of the research questions. After developing the

Table 1 - Recommended knowledge, attitudes, and skills on IPV. Topics in blue are tackled in medical schools in Mozambique.

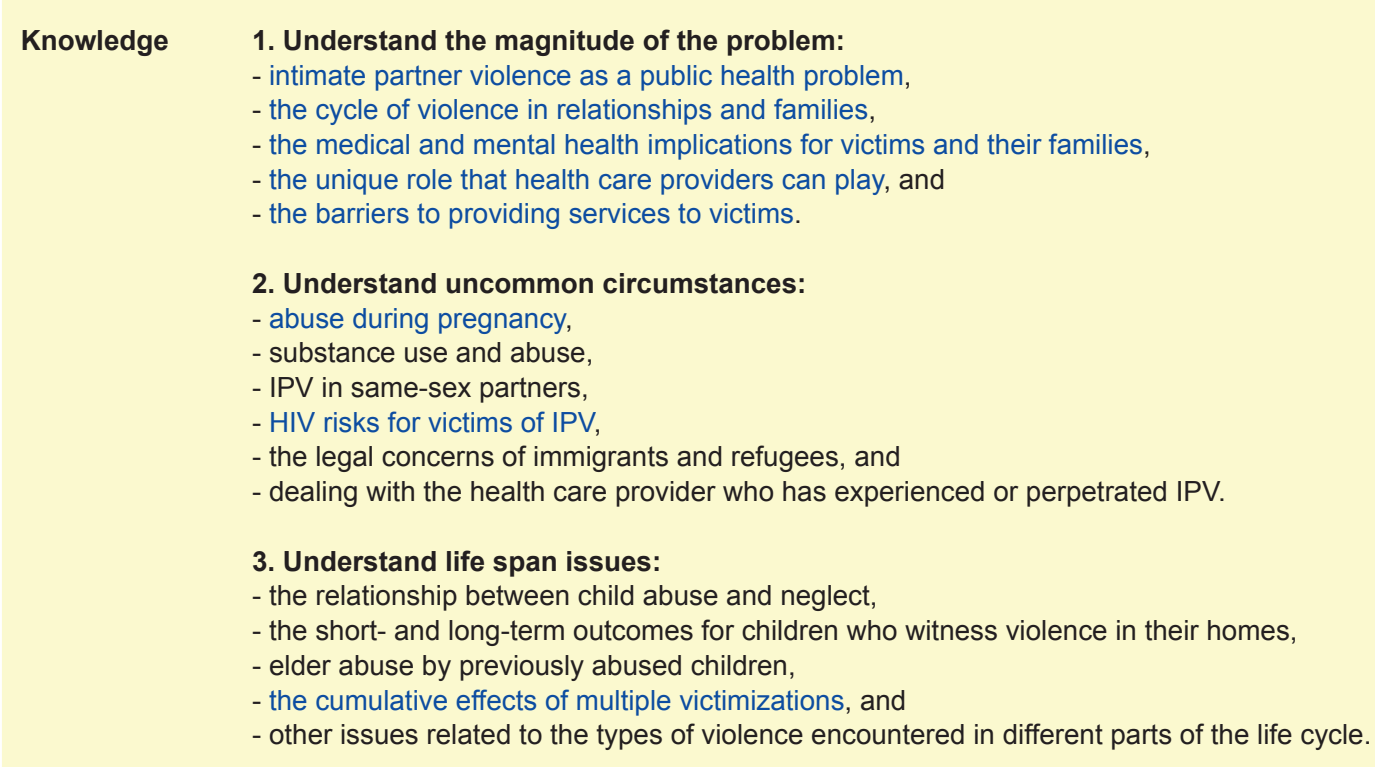

\section{Understand legal options and reporting requirements:}

- be aware of the requirements for reporting intimate partner violence,

- be aware of the role in providing epidemiologic information on the numbers of victims and the patterns of abuse.

Attitudes

1. Treatment and intervention

- ensure patient confidentiality,

- be understanding, sensitive, and patient, and

- provide support in a respectful, non-judgmental manner.

\section{Safety}

- effectively intervene without exposing the patient (or provider) to greater danger: interview patients in private, maintain separation from an accompanying partner, ensure confidentiality, and provide privacy and anonymity to protect the victim's safety.

\section{Availability}

- be accessible for future contacts by the victims.

Skills

\section{Identification; ability to:}

- screen universally,

- ask questions appropriately to recognize victims of abuse,

- obtain a history of abuse,

- determine the patient's immediate risk of danger,

- assess the patient's mental health needs,

- identify types of abuse against the patient or other family members through a physical and psychological asessment, and identify general and specific signs and symptoms of distress in victims of abuse.

\section{Reporting; ability to}

- develop injury body maps, and

- manage abuse assessment screens. 
first picture, we contacted the deans of each medical school and requested contact details of curriculum development coordinators from each medical school. As such, five curriculum developers from each of the five medical schools were contacted and four participated in individual semi-structured interviews. These were set up via e-mail and/or phone, taking the collected information as the starting point (see Appendix 2: https://www.actamedicaportuguesa.com/revista/index.php/amp/article/view/12049/Appendix_02.pdf). Additional documents, modules and information to enrich the information were requested from each interviewee. All interviews were audiotaped and transcribed. The transcripts were sent to the curricula developers for verification.

This study is part of a PhD protocol that was reviewed and approved by the Institutional Bioethics Committee for Health, Faculty of Medicine/Maputo Central Hospital (CIBS FM\&HCM, with approval number CIBS UEM\&HCM/006/2015).

\section{RESULTS}

Table 1 provides a detailed elaboration of key curriculum areas. Items in blue are currently being addressed in Mozambique's medical school curricula.

What learning aims are put forward in view of an IPV curriculum? Overall, only limited systematic attention is paid to IPV in Mozambican medical school curricula. The analysis of the scarce modules available is discussed below and mapped in Tables 2 and 3; topics explicitly addressed in the modules are printed in bold. Of course, the adopted analysis focus may overlook non-systematic attempts of medical teaching staff to address IPV ad hoc or in the context of cases. As stated earlier, competence development in general and IPV-competence development, in particular, need to be addressed continuously.

\section{Knowledge}

In relation to bodily injuries (rape, physical assault), students are introduced to aspects of health education. In the module integrated into the Obstetrics and Gynaecology (OB/GYN) rotation as sexual abuse, students get to know definitions of sexual abuse, rape, and rapists. They are also introduced to the impact of rape on reproductive health, the consequences of sexual abuse, the risk factors, the physical and emotional and behavioural indicators of sexual abuse and barriers to diagnosing it.

One medical school presented a module on Sexual and Reproductive Health (SRH) that includes themes about sexuality, the development of sexuality, sexual orientations and identities, healthy relationships, sexual and reproductive health rights (SRHR) and sexual violence and genderbased violence (GBV). In this SRH module, the following items are addressed to reduce GBV: respect for sexual and reproductive rights; acceptance of domestic violence (DV) by perpetrators and victims; intention to abstain from sex; intention to be faithful; knowing sexual rights and duties; code of conduct: when is a relationship healthy?

In the module "Integrated care for victims of sexual violence in Mozambique", students are required to explain sexual violence and GBV and to identify the role of Health Units in the care of sexual violence victims.

\section{Skills}

In the module "Sexual Abuse integrated into the $\mathrm{OB} /$ GYN" rotation, students are introduced to skills to manage abuse, including physical examination, follow-up of victims of abuse and adopting a flow chart to deal with Sexual Transmitted Infections related to sexual assault.

In the module "Integrated care for victims of sexual violence in Mozambique", students are trained to understand integrated care for victims of sexual violence. They are also trained to relate the critical players in the care of sexual violence victims and their responsibility. Students are taught to carry out evaluations of case scenarios of sexual violence victims that include their informed consent, clinical history and circumstances of the incident, physical examination and collection of medical and forensic details. Students are trained to implement therapy and prophylaxis according to clinical evaluation data, to follow up on sexual violence cases and identification of routine needs. Lastly, students are trained to establish a referral and response system with the different sectors/services involved and to perform an appropriate and timely collection and recording of data.

\section{Attitudes}

In the module integrated into the OB/GYN rotation as sexual abuse, students are introduced to ethical aspects such as respecting the privacy of the victims and avoiding showing impatience or contempt. Students are also trained to tell the patient that (s)he can control the examination and can ask to stop anytime they feel uncomfortable. They are also encouraged to deal with the victims in a non-emotional or non-judgmental way and if necessary, to translate the consultation into the language of the victim. Refraining from presenting conclusions about a diagnosis or asking about the possibility of sexual abuse until victims are fully dressed and the examination is over, could also be linked to attitudes being developed in students during the OB/GYN module.

In the module "Integrated care for victims of sexual violence in Mozambique", students are required to recognize the importance of integrated care for SV victims and to explain the aspects that ensure respect and dignity for sexual abuse victims.

\section{What are the teaching and learning strategies to pursue the development of IPV competencies?}

Table 3 integrates the findings from the curriculum analysis. The teaching strategies seem to be limited to lectures (supported with PowerPoint presentations), brainstorming activities, case study discussion, small group discussion, community health practice and are also linked to bedside teaching. One university adopted a Problem-Based Learning approach; all others could be labelled as embracing a conventional medical curriculum approach. 
$\frac{3}{0}$
$\frac{0}{0.0}$
$\frac{0}{0}$
$\frac{0}{0}$
$\frac{0}{0}$
$\frac{0}{m}$

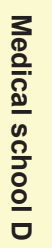

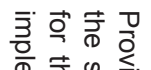

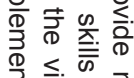

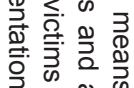

은의 울

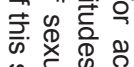

की

중. 융

ज.

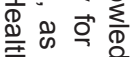

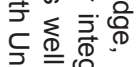

क्र के क्ष

옹 $\frac{\mathbb{0}}{\mathrm{O}} \frac{\mathrm{\phi}}{\mathrm{O}}$

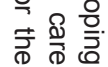

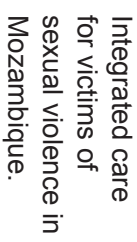

为

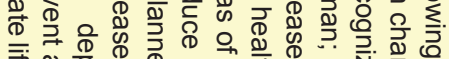

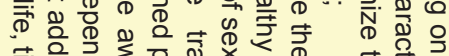

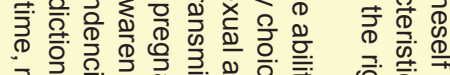

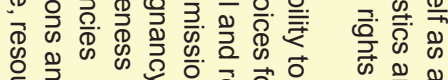

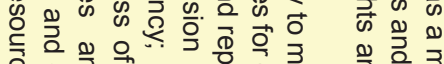

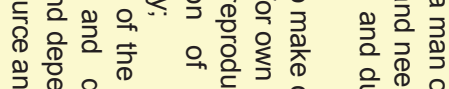

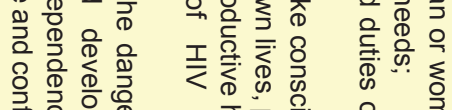

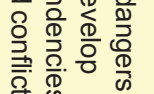
焉

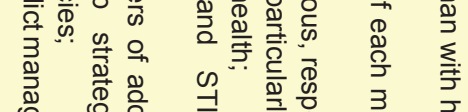

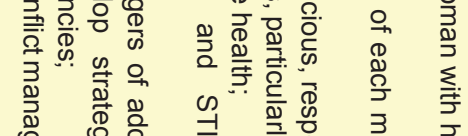

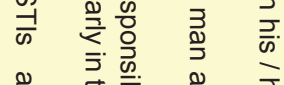

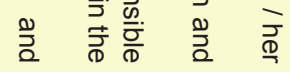

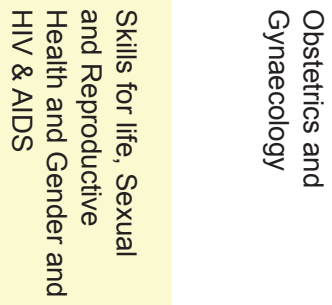

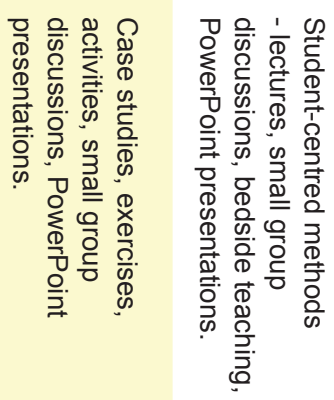

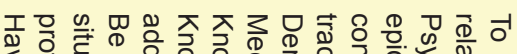

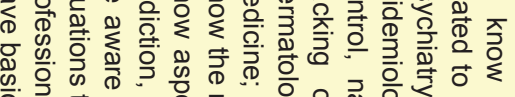

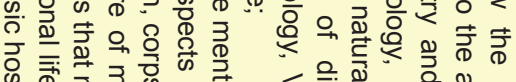

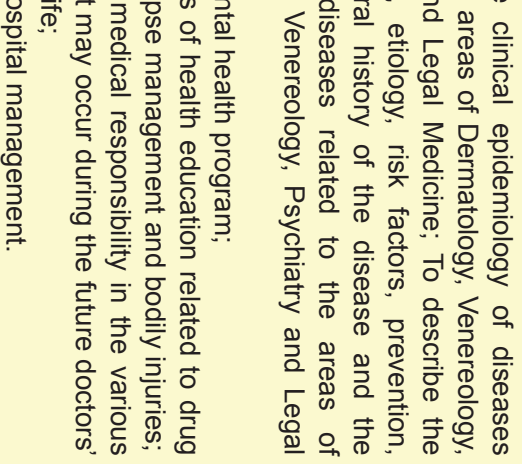
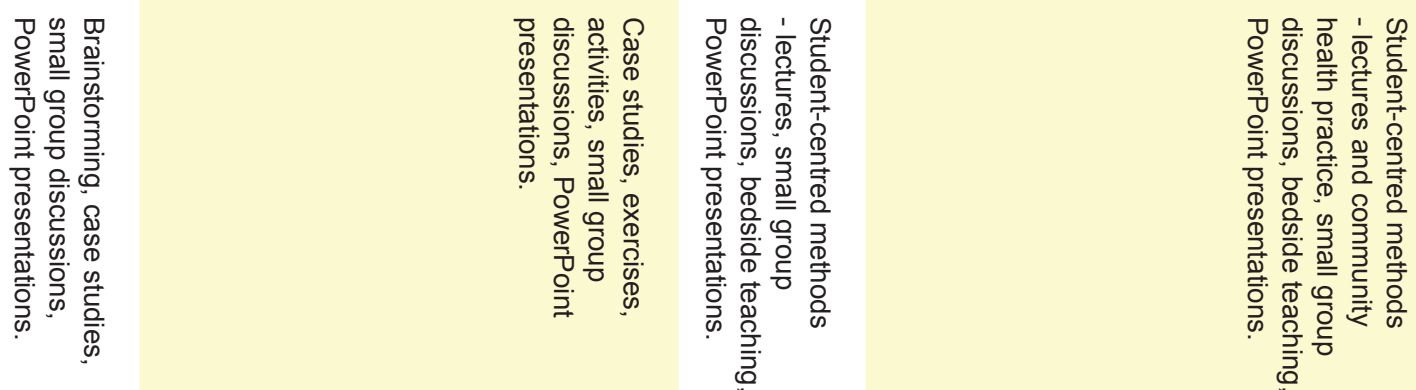

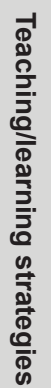
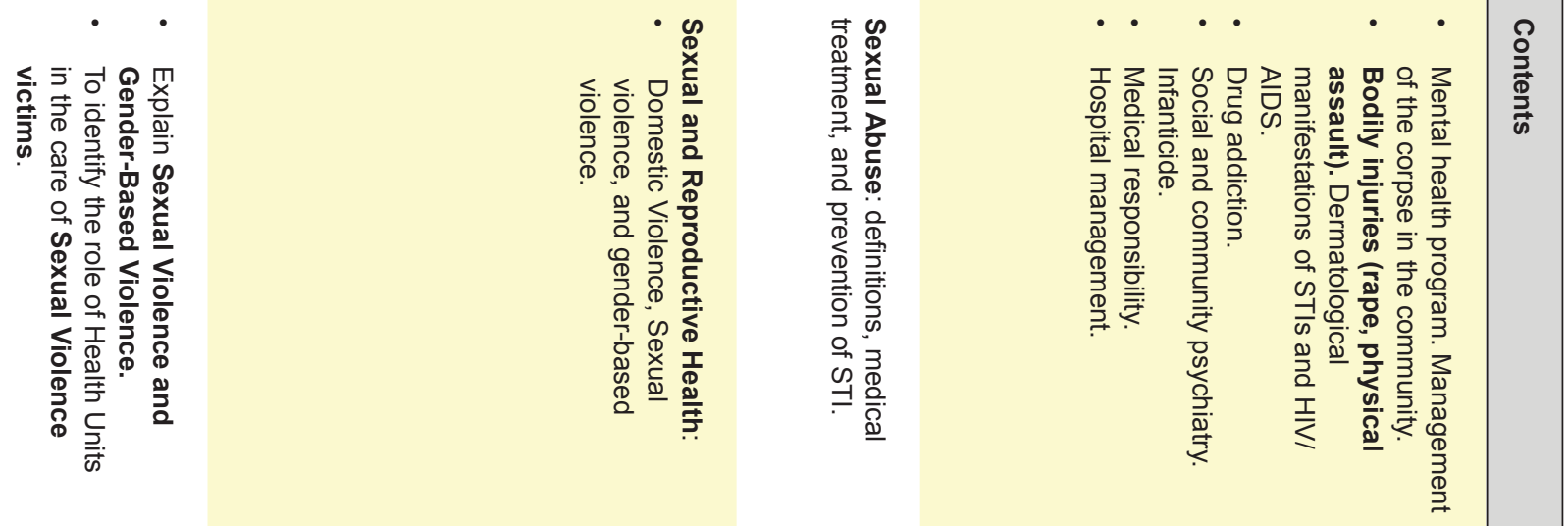


\section{What assessment approaches are stressed?}

Table 3 points out that one medical school adopts oral exams that consist of an oral defence of a report alongside a discussion of the lecture topics, and multiple-choice questions (MCQs). Hardly any specific information could be collected about assessment methods used in medical curricula of other universities.

\section{In the context of what modules or disciplines is IPV tackled?}

Table 4 integrates the answers to this key question. When it comes to the module or medical discipline context in which IPV is addressed, medical curricula seem poorly developed. In one medical school, IPV content is explicitly addressed in the curriculum via a Community Health course that deals with bodily injuries (rape, physical assault). In two other medical schools, modules about OB/GYN, Skills for life, Sexual and Reproductive Health and Gender and HIV \& AIDS and Forensic Medicine reflect a partial focus on IPV. The IPV-related matter seems integrated into OB/ GYN courses with a focus on sexual abuse: medical treatment and prevention of sexual transmitted infections. In the Skills for life, Sexual and Reproductive Health and Gender and HIV \& AIDS module, the focus is on SRH: DV, sexual violence and GBV. In the Forensic Medicine course, sexual violence is addressed: documenting cases of SV and integrated care for victims of SV in Mozambique.

\section{In what phase of the medical curriculum is IPV ad- dressed?}

As to the curriculum phase in which IPV is being addressed, IPV topics are introduced from the fourth year and fifth year in one medical school to the sixth year in another medical school. In one medical school, information about the time spent on IPV content could be defined: two hours per week during one semester.

\section{Who are the teachers taking responsibility for the IPV content?}

The medical schools that explicitly focus on IPV content, involve medical doctors from a specific discipline (e.g. OB/
GYN), who also take care of IPV.

\section{Curriculum developers' feedback on interview tran- scripts}

The curriculum developers from the 4 medical schools concurred with the information extracted from the interviews. We tried to contact curriculum developers for all the medical schools, but only four participated in the study. The following quotations illustrate how their input mainly confirms the findings reported above.

For instance, they confirm that IPV content is dealt with during both the pre-clinical and clinical years.

"The contents are distributed throughout the medical degree, implicitly or not. In terms of violence, the focus lies on all the disciplines that cover the topic. In addition to Obstetrics and Gynaecology, forensic medicine, in surgery and traumatology rotations, we also address IPV." (medical schools $\mathrm{C}$ and $\mathrm{E}$ ).

When asked if the curriculum as defined on paper matches the actual curriculum, the curriculum developers from all medical schools answered negatively: "(...) we will improve the monitoring process and see the relationship between what is written and what happens." (medical school C) "(...) in some subjects, we add some things and we give the teacher the opportunity to change." (medical school E).

Focusing on instructional strategies, the earlier findings were clearly confirmed: "The predominant method in clinical areas is the clinical approach, essentially a discussion of cases." (medical schools B, C and E ). "Now, if it is suitable for these cases (IPV): most probably not." (medical school C)."We have theoretical classes, then we have specific classes. In the specific classes, they (the students) prepare the lecture that they will deliver to the community", "roleplay". (medical school B).

As far as the assessment approaches are concerned, the following quotation is exemplary for the current situation: "Assessment of students is the worst aspect in the current curriculum. It often has no relation to educational goals, in many ways students refer to the assessment as unfair, as the characteristics of our assessment are not designed for

Table 3 - IPV curriculum in medical schools

\begin{tabular}{|c|c|c|c|c|c|c|c|}
\hline $\begin{array}{l}\text { Medical } \\
\text { School }\end{array}$ & $\begin{array}{l}\text { Type of Medical } \\
\text { School }\end{array}$ & $\begin{array}{l}\text { Module/ } \\
\text { discipline }\end{array}$ & Teacher & $\begin{array}{l}\text { Teaching/ } \\
\text { learning strategies }\end{array}$ & $\begin{array}{l}\text { Assessment } \\
\text { approach }\end{array}$ & Content & $\begin{array}{l}\text { Year of } \\
\text { induction }\end{array}$ \\
\hline A & Public & $\mathrm{N} / \mathrm{A}$ & $\mathrm{N} / \mathrm{A}$ & $\begin{array}{l}\text { Student-centred } \\
\text { methods }\end{array}$ & $\mathrm{N} / \mathrm{A}$ & $\mathrm{N} / \mathrm{A}$ & $\mathrm{N} / \mathrm{A}$ \\
\hline B & Public & $\begin{array}{l}\text { Community } \\
\text { health } \mathrm{X}\end{array}$ & Medical doctor & $\begin{array}{l}\text { Student-centred } \\
\text { methods }\end{array}$ & $\begin{array}{l}\text { Oral exam (defence } \\
\text { of the report + } \\
\text { lecture topics) }\end{array}$ & $\begin{array}{l}\text { Bodily injuries } \\
\text { (rape, physical } \\
\text { assault) }\end{array}$ & $5^{\text {th }}$ \\
\hline C & Public & N/A & $\mathrm{N} / \mathrm{A}$ & $\begin{array}{l}\text { Student-centred } \\
\text { methods }\end{array}$ & N/A & $\mathrm{N} / \mathrm{A}$ & N/A \\
\hline D & Public & $N / A$ & $N / A$ & $\begin{array}{l}\text { Student-centred } \\
\text { methods }\end{array}$ & $N / A$ & $\mathrm{~N} / \mathrm{A}$ & $N / A$ \\
\hline$E$ & Private & $N / A$ & $\mathrm{~N} / \mathrm{A}$ & $\begin{array}{l}\text { Problem-Based } \\
\text { Learning }\end{array}$ & $\mathrm{N} / \mathrm{A}$ & $\mathrm{N} / \mathrm{A}$ & $\mathrm{N} / \mathrm{A}$ \\
\hline
\end{tabular}


Table 4 - Relevant medical schools` modules on IPV

\begin{tabular}{|c|c|c|c|c|}
\hline Medical School & Discipline/subject & Instructor & Module Designation & $\begin{array}{l}\text { Year of } \\
\text { Induction }\end{array}$ \\
\hline A & $\mathrm{N} / \mathrm{A}$ & $\mathrm{N} / \mathrm{A}$ & $\mathrm{N} / \mathrm{A}$ & $\mathrm{N} / \mathrm{A}$ \\
\hline B & Community health $\mathrm{X}$ & Medical doctor & Bodily injuries (rape, physical assault). & $5^{\text {th }}$ year \\
\hline C & $\begin{array}{l}\text { Obstetrics and } \\
\text { Gynaecology }\end{array}$ & Medical doctor & $\begin{array}{l}\text { Sexual Abuse: definitions, medical treatment, } \\
\text { and prevention of STI. }\end{array}$ & $4^{\text {th }}$ year \\
\hline D & $\begin{array}{l}\text { Skills for life, Sexual and } \\
\text { Reproductive Health and } \\
\text { Gender and HIV \& AIDS }\end{array}$ & Medical doctor & $\begin{array}{l}\text { Sexual and Reproductive Health: Domestic } \\
\text { violence, Sexual violence, and gender-based } \\
\text { violence. }\end{array}$ & $\mathrm{N} / \mathrm{A}$ \\
\hline $\mathbf{E}$ & Forensic Medicine & Medical doctor & $\begin{array}{l}\text { Sexual violence: documenting cases of } \\
\text { sexual violence. } \\
\text { Integrated care for victims of sexual violence } \\
\text { in Mozambique. }\end{array}$ & $6^{\text {th }}$ year \\
\hline
\end{tabular}

the purpose that is proposed. Usually, the assessment used in the Faculty of Medicine is an assessment of knowledge. That is, you assess the first part of Miller's pyramid, you assess the knowledge." (medical school C).

Lastly, the respondents confirm that the focus on IPV remains restricted in Mozambican medical curricula: "First of all, I have to realize that the student we are training is a student who will be a general practitioner. Secondly, I realize that the training that he/she receives in medical school is only one part of the whole of medical training that $s($ he) will have throughout his life. And thirdly, I realize that if I had to teach all the details the students would never finish the medical degree. Therefore, I support the idea that the approach that should be taken is an approach in the general context of domestic violence (DV) or general violence." (medical school C).

\section{DISCUSSION}

The primary purpose of this study was to map the stateof-the-art of IPV education in current Mozambican medical curricula. The findings were based on information from five key medical schools. The analytical findings were confirmed after receiving feedback from interviewees.

The nature of the details of the IPV curriculum, when analysed based on a curriculum framework, remains critical. The IPV curriculum content seems to be regarded as a stand-alone topic or module within other curriculum subjects. Teaching methods remain conventional, with only one school adopting a problem-based learning approach. In most medical schools, it was difficult to identify which teachers focus on IPV, what time is allocated to the topic, or which assessment methods are used. This can be explained by the observation that only in one medical school IPV is integrated as a subject in the formal curriculum. These findings confirm what has been found in the literature, namely that critical IPV curriculum content is hardly offered consistently throughout medical education. We also discovered that when IPV is addressed, this only occurs during a short period of time, mainly at a single point in the medical education program, and mostly limited to one type of violence.

The findings push the current discussion towards an urgent redesign of current curricula. Firstly, the IPV curriculum content should be integrated throughout medical education, starting in the pre-clinical years and continuing during clinical years. The current focus on IPV only during clinical years is not effective. Another critical observation is that IPV is mainly seen as yet another type of violence and also primarily tackled in the context of Orthopedics or Surgery subjects. We recognize that IPV is one of the many types of violence that should be addressed in Mozambican curricula, but it is vital that it is also taken into account in the context of other disciplines in undergraduate curricula, such as Neurology, Urology, Gastroenterology, Internal Medicine, Psychiatry, Pediatrics, Emergency Medicine, apart from Surgery and Orthopedics.

Building on recommendations of Thomas and colleagues, ${ }^{17}$ we suggest the following approach to redesign current curricula:

- Boosting the curriculum design process: specific task force members of the curriculum reform should be present at all meetings related to IPV, carry out a periodic review of the curriculum, screen all assessment approaches, organize informal discussions with students and teachers about the curriculum, and foresee yearly formal curriculum planning meetings.

- Implementing educational changes: foster the adoption of clinical simulations related to IPV, support the use of information technology to instigate medical training in IPV, introduce online approaches such as asynchronous group work and setting up flipped classroom designs.

- Faculty development: train medical staff to guarantee their mastery of the IPV curriculum content, involve medical staff in the development of an IPV training program, develop half-day or two-day workshops to foster interaction with staff from other medical institutions. 
This is the first study related to IPV curriculum contents in medical schools conducted in Mozambique. We hope the description of essential IPV curriculum contents for medical schools contributes to the design and development of interventions aiming at prevention and control of IPV. The information might also help to adapt the role of Mozambican medical schools in the prevention and provision of IPV related care, in terms of teaching methods, teaching content and its scientific basis. The latter can build on updated information about IPV and attention being paid to the integration of information about National Policies. The study especially stresses the need to develop curricula that pay more in-depth and consistent attention to IPV.

The present study is not without limitations. First, the study could be enhanced with the voice of additional stakeholders, such as medical students, medical teachers and ultimately IPV victims. Though based on a clear curriculum framework, data collection was marred by the fact that interviewers were not professional curriculum designers well acquainted with the nature of curriculum design, nor with a clear mastery of instructional theory and practice. Lastly, what stakeholders describe as the "curriculum" may differ from its actual implementation. Additionally, our emphasis on a systematic focus on IPV may have neglected interesting and inspiring ad hoc interventions of medical staff about IPV.

\section{CONCLUSION}

Our findings strongly suggest there is room for changes in current IPV curriculum design in medical schools in Mozambique. Since medical doctors are often the first and sole point of contact to identify and tackle IPV, their training is of key importance: especially in the Mozambican context where the prevalence of IPV is high, upgrading medical expertise should be a priority. Looking from a wider angle, the latter statement should be broadened to all healthcare providers playing a role in prevention, curation and restoration of IPV incidents as in the reality of Mozambique there are all kinds of other practitioners, other than medical doctors, who establish the first point of contact with victims. In addition, there are many areas where people have no access to a medical doctor but are only attended by other practitioners.

\section{REFERENCES}

1. WHO. Intimate Partner Violence and Alcohol Fact Sheet. [accessed 2017 Oct 03]. Retrieved from: https://www.who.int/violence_injury_ prevention/violence/world_report/factsheets/ft_intimate.pdf.

2. Ramsay J, Rutterford C, Gregory A, Dunne D, Eldridge S, Sharp D, et al. Domestic violence: knowledge, attitudes, and clinical practice of selected UK primary healthcare clinicians. Br J Gen Pract. 2012;62:e647-55.

3. Gadomski AM, Wolff D, Tripp M, Lewis C, Short LM. Changes in health care providers' knowledge, attitudes, beliefs, and behaviors regarding domestic violence, following a multifaceted intervention. Acad Med. 2001;76:1045-52.

4. Lawoko S, Sanz S, Helström L, Castren M. Screening for intimate partner violence against women in healthcare Sweden: prevalence and determinants. ISRN Nurs. 2011;2011:1-7.

5. Almutairi GD, Alrashidi MR, Almerri AT, Kamel MI, El-Shazly M. How to screen for domestic violence against women in primary health care

\section{ACKNOWLEDGEMENTS}

Firstly, the first author wishes to thank her husband and sons for the support. The authors wish to thank the Faculty of Medicine at Eduardo Mondlane University, the Faculty of Health Sciences of the Catholic University of Mozambique, the Faculty of Medicine of University of Zambeze, the Medicine Course of the Higher Institute of Science and Technology of Mozambique and the Faculty of Medicine of UniLúrio University, for agreeing to participate in this study. The authors would also like to thank the Flemish VLIR agency for funding the IPV related $\mathrm{PhD}$ at Ghent University and University Eduardo Mondlane (Maputo, Mozambique). We would also like to send special thanks go to the research assistants.

\section{PROTECTION OF HUMANS AND ANIMALS}

The authors declare that the procedures were followed according to the regulations established by the Clinical Research and Ethics Committee and to the Helsinki Declaration of the World Medical Association.

\section{DATA CONFIDENTIALITY}

The authors declare having followed the protocols in use at their working center regarding patients' data publication. The data that support the findings of this study are available on request from the corresponding author, BM. The data are not publicly available due to the contained information that could compromise the privacy of research institutions.

\section{CONFLICTS OF INTEREST}

None declared.

\section{FUNDING SOURCES}

This study was supported by VLIR-UOS (see link http:// www.vliruos.be/en/ongoing-projects/overview-of-ongoingprojects/iuc/institutional-cooperation-with-eduardo-mondlane-university-(uem),-mozambique/ ), as part of "Addressing Intimate Partner Violence: implications for medical curricula in Mozambique", $\mathrm{PhD}$ research project. The contract number of the project was ZIUS2016AP019. The funders had no role in the preparation of the manuscript.

centers. Alexandria J Med. 2013;49:89-94

6. Wood L. Simulation as a training tool for intimate partner violence screenings. Clin Simul Nurs. 2016;12:8-15.

7. Gennari F, Harris-Sapp T, Simmons K, Messner LA. Lessons from the Gender-Based Violence Initiative in Tanzania.; 2016. [accessed 2016 Mar 29]. Retrieved from: https://aidsfree.usaid.gov/sites/default/ files/2016.03.29_gbvi_moz_report_nidaapproved_rktagged.pdf.

8. Simmons J, Brüggemann AJ, Swahnberg K. Disclosing victimisation to healthcare professionals in Sweden: a constructivist grounded theory study of experiences among men exposed to interpersonal violence. BMJ Open. 2016;6:e010847.

9. Fawole O, Van Wyk JM, Adejimi A. Training on prevention of violence against women in the medical curriculum at the University of Ibadan, Nigeria. African J Heal Prof Educ. 2013;5:75.

10. Van Den Ameele S, Keygnaert I, Rachidi A, Roelens K, Temmerman M. 
The role of the healthcare sector in the prevention of sexual violence against sub-Saharan transmigrants in Morocco: a study of knowledge, attitudes and practices of healthcare workers. BMC Health Serv Res. 2013;13:77

11. Lawoko S, Seruwagi GK, Marunga I, Mutto M, Ochola E, Oloya G, et al. Healthcare providers' perceptions on screening for Intimate Partner Violence in healthcare: a qualitative study of four health centres in Uganda. Open J Prev Med. 2013;03:1-11.

12. Osório $C$. Entre a denúncia e o silêncio. Análise da aplicação da lei contra a violência doméstica (2009-2015). Maputo; 2016. [accessed 2017 Oct 3]. Retrieved from: http://www.wlsa.org.mz/entre-a-denunciae-o-silencio/.

13. World Health Organization, Pan American Health Organization. Strengthening the capacity of health-care providers to address violence against women. $\mathrm{WHO}$ and PAHO Expert Meeting on Curricula Development.; 2015. [accessed 2015 Jun 8]. Retrieved from: https:// www.paho.org/hq/index.php?option=com_content\&view=article\&id=130 22:workshop-strengthening-capacity-health-systems-prevent-respondviolence-against-women-2017\&ltemid=42281\&lang=en .

14. Temmerman M. Research priorities to address violence against women and girls. Lancet. 2015;385:e38-e40.

15. Taba H. Curriculum development; theory and practice. New York: Harcourt, Brace \& World; 1962.

16. Stobo JD, Salmon ME. Confronting chronic neglect : the education and training of health professionals on Family Violence Institute of Medicine Galveston, Galveston, TX Nursing, Baltimore, MD of Law, Georgetown University Law College of Medicine, lowa City, IA Division. Educ Train. $2001 ; 3313$. 